\title{
A case of leucism in the slow worm (Anguis fragilis)
}

\author{
HOLLY HARKNESS ${ }^{1 *}$ \& STEVEN J. R. ALLAIN ${ }^{2}$ \\ ${ }^{1}$ The Ecology Consultancy, Tempus Wharf, 33a Bermondsey Wall West, London, UK \\ ${ }^{2}$ Cambridgeshire \& Peterborough Amphibian and Reptile Group \\ "Corresponding author e-mail: holly.harkness@hotmail.com
}

$T^{\text {Tes }}$ he slow worm (Anguis fragilis) is a limbless lizard found across Europe and south-west Asia (Beebee \& Griffiths, 2000). Colour variations and abnormalities in slow worms are rarely observed which may in part be due to their cryptic nature. Examples of such abnormalities include melanism (Gleed-Owen, 2012), albinism (Knight, 1966) and blue ventral coloration (Hails, 2017). However, only one case of leucism has been recorded previously; in a new born slow worm (Jablonski \& Purkart, 2018). Leucistic reptiles have diminished numbers of iridophores in the skin associated with a low number of, or no, melanophores and xanthophores (Bechtel, 1991). Here we report a further case of leucism, this time from a sub-adult slow worm.

On the 25th April 2020 a routine reptile survey was undertaken of a derelict plant nursery $\left(51^{\circ} 37^{\prime} 57.7^{\prime \prime} \mathrm{N} 0^{\circ}\right.$ $04^{\prime} 24.9^{\prime \prime} \mathrm{W}$ ) located in a predominantly urban area. The site had recently been cleared of brambles and scrub and was thought to support a small population of slow worms. During the survey, a leucistic sub-adult $A$. fragilis (Fig. 1) was found under a $1 \mathrm{~m}^{2}$ square of bitumen roofing felt, laid to assist the survey effort. At the time, the weather was overcast and warm.

The leucistic $A$. fragilis was approximately $21 \mathrm{~cm}$ in length with an intact tail. The coloration can be described as an almost translucent pale pink which transitioned to a very pale pink towards the tail. This coloration made the dark eyes of the individual stand out more than normal. No vertebral stripe or lateral coloration were visible (Fig. 1). After photographs were taken, the individual was returned to the point of capture. A juvenile and an adult male slow worm with typical coloration were also seen under other artificial refuges within the same locality during the survey.

Jablonski \& Purkart (2018) comment that leucism is rare in Anguis spp. However, among other reptiles it is not uncommon (Krecsák, 2008) and leucistic individuals are particularly favoured by snake breeders. In the wild, it is reasonable to assume that leucism would increase the chances of predation so that in the case of this sub-adult slow worm, the likelihood of it reaching sexual maturity would be reduced. Both recorded cases of leucism in $A$. fragilis have come from observations in England despite the species' large geographic range. Jablonski \& Purkart (2018) suggested that the particularly low recording rate of leucistic individuals may be due to their misidentification as albinos.

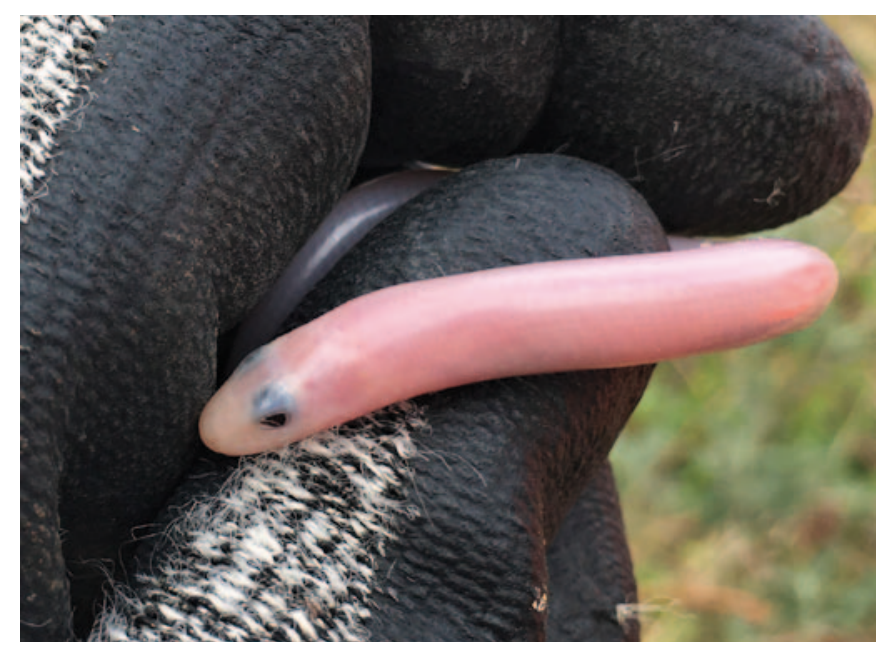

Figure 1. Sub-adult leucistic slow worm (A. fragilis)

\section{REFERENCES}

Bechtel, H. B. (1991). Inherited color defects: Comparison between humans and snakes. International Journal of Dermatology 30: 243-246.

Beebee, T. J. C. \& Griffiths, R. A. (2000). Amphibians and Reptiles: A Natural History of the British Herpetofauna. London, HarperCollins. p. 270.

Gleed-Owen, C. (2012). Anguis fragilis (slow-worm): Melanism. Herpetological Bulletin 120: 34-35.

Hails, E. L. (2017). The first record of a slow-worm (Anguis fragilis) from the UK with blue ventral scales. Herpetological Bulletin 140: 37.

Jablonski, D. \& Purkart, A. (2018). First report of leucism in Anguis fragilis. Herpetological Bulletin 145: 35-36.

Knight, M. (1966). Birth of albino slow-worms. British Journal of Herpetology 3: 259-260.

Krecsák, L. (2008). Albinism and leucism among European Viperinae: a review. Russian Journal of Herpetology 15: 97-102. 